\title{
一般演題
}

\section{透析器機 !}

座長 小野 利彦（京都第一赤十字病院透析）

Protein Losing Hemodialysis の経験

(664)

$$
\begin{array}{rlll}
\text { 西北神 HD クリニック } & \text { 申 } & \text { 曽洙, 新光 } & \text { 聡子 } \\
\text { 兵庫医科大学人工透析部 } & \text { 藤田 } & \text { 嘉一, 井上 } & \text { 聖士 } \\
\text { 住吉川病院 } & \text { 坂井 } & \text { 瑠実, 西岡 } & \text { 正登, 駒場啓太郎 } \\
\text { 甲南病院中央人工腎臟部 } & \text { 内藤 } & \text { 秀宗, 宮崎 } & \text { 哲夫 }
\end{array}
$$

各種 protein-permeable hemofilter の性能評価 一特に小分子量物質の除去率と

UFR の経時変化について

$$
\begin{aligned}
& \text { 新生会第一病院 高木 豊巳, 福田 郁夫, 桜井 謙次 } \\
& \text { 鄭大基, 斉藤 明, 太田 和宏 }
\end{aligned}
$$

透析患者の血液保存法（第 1 報）Kについて

$$
\begin{aligned}
& \text { 鷺沼人工腎臟石川クリニック尾崎 真啓, 藤森真理子, 成合加代子 } \\
& \text { 前川 和子, 浜田とみ子, 中本 里美 } \\
& \text { 石川 丈之 } \\
& \text { 慶応義墪大学腎臟センター 小森 正樹, 山吉 亘 } \\
& \text { 関東労災病院人工腎臓室川崎 忠行, 林正博, 前田貞亮 }
\end{aligned}
$$

ECUM 時およびHD 時における白血球隇少症について

$$
\begin{array}{rll}
\text { 杏林大学透析センター } & \text { 武田 } \text { 久雄, 七海由香里, 小幡富士雄 } \\
& \text { 三浦 律子, 木村 常雄 } \\
\text { 同第 } 1 \text { 内科 } & \text { 副島 昭典, 北本 清, 長沢 俊彦 }
\end{array}
$$




\section{Protein Losing Hemodialysis の経験}

申 曾 新光 聡子 藤田 嘉一* 井上 聖士* 坂井 留実 ${ }^{* *}$ 西岡 正登**駒場啓太郎**内藤 秀 宗***宮崎 哲夫***

西北神 $\mathrm{HD}$ クリニック 兵庫医科大学人工透析部* 住吉川病院 $* *$ 甲南病院中央人工腎臟部***

〔はじめに〕 EVAL-C 膜はかなり多量の蛋白を漏出 する透析膜であり，この膜を用いた血液透析（Protein Losing Hemodialysis : PLHD) の興味深い特性を検討 した.

〔蛋白漏出量と Sieving Coefficient〕 7 例 1 時間目の ECUM から，EVAL-C 膜 HFK の Ultrafiltrate には平 均 $488 .{ }^{4} \mathrm{mg} / \mathrm{d} l$ の蛋白が存在し, その $80 \%$ Albumin で あり, 少量の $\operatorname{IgA} ・ \operatorname{IgG} も$ 含まれていた。 $\mathrm{SC}$ の平均值 は, IgG 0.034, Albumin 0.09, Prolactin 0.48, $\beta_{2}$ m 0.635 であった.

〔PLHD の透析前後の変化〕 EVAL-C 膜 HFK と Cuprohan 膜 HFK を用いた同一 6 例各 1 回の透析を比 較すると, PLHD で透析後に TP・Albumin・Myoglobin が低下し, UN ・ Creat・UA・P の低下と Ca の上昇が 有意に小さかった。

〔PLHD の臨床経過〕外来透析 6 例について 5 力月 間の PLHD を実施したのち, Cuprophan 膜透析に移行 して,その経過を観察した。

$\mathrm{TP} \cdot$ Albumin ・ Ca $\operatorname{IgG} ・ \beta_{2} \mathrm{~m}$ は PLHDによって低 下し, IgA $\cdot \alpha_{2}$-globulin $\cdot$ Fibrinogen $\cdot$ Cholesterol $\cdot T G$. 血圧はPLHDによって上昇した，PLHDによって，PT は短縮し, $\mathrm{Hb} \cdot \mathrm{UN} \cdot \mathrm{Creat} \cdot \mathrm{UA} \cdot \mathrm{K} \cdot \mathrm{P}$ は上昇傾向を 示した。また，かゆみの強い 1 例はPLHD でかなり改善 した。な押 PLHD 終了前の時点で 1例の Shunt 血流の 減少と，1例の心不全症状の発現を見たがともに一時的 なものであった。

〔おわりに〕われわれのPLHD の成績の多くは斉藤 らの同じ膜によるHDF の成績と一致して扔り，興味深 い。この新しい血液透析について，さらに慎重に検討し ていきたいと思う。

\section{各種 Protein permeable hemofilter の性能評価 一特に 小分子量物質の除去率と UFR の経時的变化について}

高木 豊巳 福田 郁夫 桜井 謙次 鄭 大基 斉藤 明 太田 和宏

新生会第一病院

種々の透析困難症を持った長期透析患者を対象とし て, 我々はすでに protein permeable hemofilter を用い て HDF を行い症状の改善が得られることを報告してき た、そこで, 従来のへモフィルターでは, Protein cake
などの現象が UFR に影響することに注目して UFR の 性能を比較した，また，小分子蛋白滤過量と小分子量物 質の除去動態を比較検討した。へモフィルターとして， クラレ社製 $\mathrm{C}-2$ (EVA 膜)，東レ社製 TK-401 (PMMA 膜)，帝人社製 FF-22 (CA 膜)。また膜面積はそれぞれ $1.5 \mathrm{~m}^{2}, 2.0 \mathrm{~m}^{2}, 2.3 \mathrm{~m}^{2}$ を用いて透析患者 10 名に $\mathrm{HDF}$ を 行った.

〔結果〕膜素材の異なる TK-401 と C-2 では，アル ブミン漏出量は約 $6 \mathrm{~g}, 10 \mathrm{~g}$. 同様にクリアランスでは, $150 \sim 189 \mathrm{~m} l / \mathrm{min}, 96 \sim 130 \mathrm{~m} l / \mathrm{min}$. また，同様に 1 時間 目の UFR は平均 $38.3 \mathrm{ml} / \mathrm{mmHg} \cdot \mathrm{hr}, 10.4 \mathrm{ml} / \mathrm{mmHg}$ ・ $\mathrm{hr}$ を示したことから，TK-401 と C-2 の比較で小分子 蛋白除去と小分子量物質除去動態に相異を認めた。それ らは, Pore size および膜の性質の相異が影響されている と思われた，今後，膜素材の性質や Pore size などを考 慮に入れて，さらにより適性な膜の開発の一助となるよ う評価していきたい。

\section{透析患者の血液保存法（第 1 報） Kについて}

尾崎 真啓 藤森真理子 成合加代子 前川 和子 浜田とみ子 中本 里規 石川 丈之 小森 正樹* 山吉 亘* 川崎 忠行**林 正博**前田 貞亮** 鷺沼人工腎藏石川クリニック

慶応義塾大学腎センター* 関東労災病院人工腎臓 室**

〔はじめに〕透析患者の $\mathrm{K}$ 測定は，日常検査の不可欠 検査といえる，しかしK測定值は，全血放置にて容易に 高值を示すことが知られている，それゆえ採血後すみや かに血清分離を行わなければならない。しかし透析者穿 針後 1 時間以内屿人手不足であるため容易に血清分離が できないのが現状である．今回われわれは各種採血管を 使用し，採血より測定する間の血清分離に変わる血液保 存法について検討したのでここに報告する.

【方法）透析患者 4 例, 健常人 5 例の血液をプレイン 管, オートセップ(懸垂式遠心器使用), オートセップ(卓 上式角型遠心器使用), コアグラント・ワコーの 4 方法で 行った。なおすべての数值は血清分離值を基準とした増 加率で表わした。

【結果〕プレイン管使用 5 時間值 $13.1 \pm 6.1 \% ， 29$ 時 間值 $20.6 \pm 11.4 \%$ ，オートセップ（懸垂式）使用 5 時間 值 $3.1 \pm 2.8 \%, 29$ 時間值 $13.0 \pm 6.5 \%$ ，オートセップ(角 型）使用 5 時間值 $8.5 \pm 6.8 \% ， 29$ 時間值 $21.1 \pm 12.9 \%$, コアグラント・ワコー 5 時間值 $12.9 \pm 5.9 \% ， 29$ 時間值 $42.1 \pm 5.4 \%$ の上昇が認められた。

〔考察〕 K は全血で放置すると容易に高值を示すた め, 採血後 1 時間以内に血清分離しなければならない. 
しかし透析者穿針後 1 時間以内は容易に血清分離できな い.しかし採血より測定までの時間が 5 時間以内であれ ばオートセップを使用し血清分離相のまま保存しても, Tonks の測定許容誤差範囲内にとどめることができる ができるだけ早く分離した方が望ましい.しかし 29 時間 必要な場合は血清分離するしかないように思われる。

\section{ECUM 時および HD 時における白血球減少症について}

武田 久雄 七海由香里 小幡富士雄 三浦 律子 木村 常雄 副島 昭典* 北本 清* 長沢 俊彦* 杏林大学病院透析センター 同第 1 内科*

〔目的〕従来カプロファン膜使用時の血液透析におい て開始後 $15^{\prime}$ で白血球減少，呼吸障害㧍よび補体の活性 化の報告が見られて扔り今回, 我々はAcetate 透析液に よる血液ガスへの影響をさけるため, Bicarbonate 透析 液を用いて透析を行いさらにそれをコントロールとして 透析液のまったく関与しない ECUM 時において同様の

\section{討 論}

小野 私の方から先生にお尋ねしたいのですが，この 膜は生体膜に近い膜ということ，それから，我が国で開 発されているということで, 今後非常に注目されていく ものだろうと思います。まだまだ検討中ですので，非常 にお答えにくいかもしれませんが，まず物質除去の面で はどういうところをねらっておられるかというところ と，それから臨床的にどういうメリットを将来期待でき るか，その展望についてご意見をお聞きしたいと思いま す。

申 物質除去についてねらっている点といいますの は，本当にどのくらいということはもう全然見ておりま せん，といいますのは，従来の透析膜というものが，も ともと，ちょっと大きなものは全然抜けないというょう なものばかりしか追っていなかったということがありま すので，この膜と比べて余りにも差が大き過ぎるという ことでして，本当は，ジャンジャン，アルブミンを抜く し, IgG まで抜いてしまうというような膜は本当に必要 かなと．実は 1 万や 2 万程度まで抜けば十分ではないか と. 6 万ぐらいでカットオフポイントを置いて，それ以 上はもう全然抜かないと。そういう膜で，それ以下は今 度はジャンジャン抜くような膜があれば非常に面白いの ではないか。 十分の膜では，本当に CDAK-350 等のセ ルロースアセテートを例外，あるいは RT-4 の PAN 膜 ぐらいを若干の例外といたしまして，ちょつと大きな分 子量のものは全然抜かなかったわけですので, その点で,
白血球減少，呼吸障害及び補体活性化などの諸現象につ いて検討を試みた。

〔方法〕対象症例怯, 安定した慢性血液透析患者の男 性 2 名, 女性 2 名. 透析扝よび ECUM に用いた透析器 の膜は, カプロファン膜, PMMA 膜, EVA 膜をそれぞ れ 5 回ずつ使用し採血部位は動脈側チューブより行いお のおのの開始直前, $15^{\prime}, 30^{\prime}, 60^{\prime}$, 終了時に扔ける白血球 数, $\mathrm{Hb}$ 值, 補体成分 $\left(\mathrm{C}_{3}, \mathrm{C}_{4}\right)$ および血液ガスについて 経時的に測定した.

〔成績・考察〕カプロファン膜, PMMA 膜, EVA 膜 を用いた本実験において，1）カプロファン膜使用時の み ECUM および透析時共に開始 $15^{\prime}$ 後に白血球の有意 な低下をみた。2）カプロファン膜使用時の白血球減少 時に ECUM 及び透析時ともに $\mathrm{C}_{3}, \mathrm{C}_{4}$ の有意な低下は 認められなかった。 3 ）白血球減少時に伴なう呼吸障害 もまた $\mathrm{PO}_{2}$ の低下もみられなかった。

アルブミン以上抜きますと，例の TG が上がったり， フィブリノーゲンが上がったりというへんてこなことが いっぱい起こってまいります。そういう点では CAPDで も PAN 膜のロスは仕方がないということで，その欠点 だけを消して，いい点だけ残るというような膜が将来出

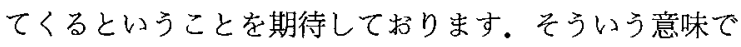
は, その辺の 5 万以下の小分子量蛋白というところが興 味深いと思って, 今, 実際には EVAL-C 膜ではなくて, 通常売っている $\mathrm{B}$ 膜の方の臨床使用などを, 症例を増や して検討を続けております。

小野 臨床的に先生が期待されているメリットという のはどういうことになりますか.

申まず何より Ht の改善という点が, プロティン ルージングの HDFでも, うちでの HEでもそうであり ますし，また同様に CAPD でも，Ht の改善という面で 非常に共通しておりますので，こ机がやはり，先生のと ころは，非常に Ht がそうでなくても高いという抢話で ございますが, 30 以上というのが当たり前というふうな 維持透析をやりたいと。そのために資すればと思ってお ります。

小野 高木先生, 臨床的な面での膜に対する期待とい うのはどういうところにございますか.

高木 いまやっている東レにしてもクラレにしても， アルブミンの量とかトータルプロティンの量でも, CA PD についてはちょつと漏れ過ぎではないかと思います 
ので，もう少しカットオフを抑えた，アルブミンが 5,000 $\mathrm{mg}$ ぐらいとか, それぐらいまで, $10 \mathrm{~g}$ ぐらいまで出て いるのですけれども，それが落とせるような，まあ，ど うしてもカットオフはなだらかになっているので，そこ ら辺をシャープに切れるような膜の開発をメ一カーの方 にもいろいろ要望しておりますけれども。

草苅 (北里大学) 申先生にちょっと放えいただき たいのですが, 先性どのグラフの中で, PLHDをやって いる段階で $\beta_{2}$-マイクログロブリンが下がったという データで, PLHDをやめられた段階でも，データのあれ がステーブルな状態で進行しているように扔見受けした のですが，その点の解釈としまして，私もちょっとやっ たことがあるのですが，確かにプロティンルージングメ ンブレンを使った場合にはそういうものは下がりますけ れども，それをやめた段階でまたもとの值に戻る傾向が 強いと思いますが，あるい和 $\beta_{2}$-マイクログロブリンの ジェネレーションがどうなっているのか, 穴の辺の解釈 をちょっと扔教えいただければありがたいと思います。

申 先生のところでは戻っでりますでしょうか。

草苅大体がもとの值に戻る傾向が強いと思っておる ますけれども。

申 本院のデー夕，実は私自身も解析に困って蚛る点

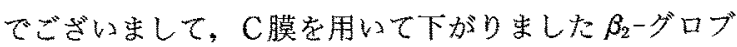
リンのレベルが, 中止して AM ネオシリーズのキュプロ ファン膜に戻って扔るわけですが，それでも，そんなに 上がってこないのです，それで，一遍下がってしまった ら，上がってくるのには時間がかかるのだろうかとか， ちょっと思ったりはして放りましたのですが，4カ月も
経過しておりますので，ちょつとその点, 解析に困って 和ります：それで，説明もできずに，そのまま実は黙つ て目をつぶって流したという次第でございます。

小野 尾崎先生に1つだけ招郎ねいたしますが，結論 では，“直ちに”ということでございましたが，“直ちに” というのは, 現実の問題として非常に難しいことだろ

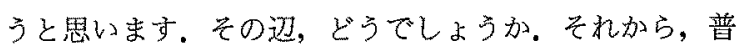
通，赤血球を残すために静置して採血しておられるとこ ろが多いと思うのですが，その影響はいかがでしょうか。

尾崎 “直ちに”ということは，大体オートセックを 使った場合, 分離して, 透析がちょっと睱になる時間が ありますので，そういう時に遠心してもら光ればいいと いうことです。それから保存方法ですか，そういう時， 主に影響するのが，採血した後，試験管に移す時に物理 的溶血なんかを起こして高值を示すことがよくありま す.

小野 武田先生のご発表について1つお非福したいの ですが, ECUM の時には，キュプロファン膜でも非常に 変化が少なかったように思いますが, 膜よりも透析液の 影響が大きいというふうに考えてよろしいのでしょう 加.

武田 透析液の影響はないと思います。

小野 それはアセテートでもバイカーボネートでも同 じでしょうか.

武田 白血球の場合ですか.

小野はい.

武田と思います。 